\title{
Seasonal variation in the fatty acid composition of milk supplied to dairies in the mountain regions of Switzerland
}

\author{
Marius COLLOMB ${ }^{1 *}$, Walter BISIG ${ }^{1,2}$, Ueli BÜTIKOFER ${ }^{1}$, Robert SIEBER ${ }^{1}$, \\ Mirjam BREGY ${ }^{2}$, Luzi ETTER $^{2}$ \\ ${ }^{1}$ Agroscope Liebefeld-Posieux Research Station ALP, 3003 Berne, Switzerland \\ ${ }^{2}$ University of Applied Sciences of Berne, Swiss College of Agriculture, 3052 Zollikofen, Switzerland
}

Received 22 November 2007 - Accepted 8 July 2008

\begin{abstract}
The influence of typical feeds from five mountain regions of Switzerland (altitude of grass-based feed (GBF) during the summer and winter seasons: $1247( \pm 465) \mathrm{m}$ and 1136 $( \pm 310) \mathrm{m}$, respectively) on the fatty acid (FA) composition of bovine milk fat was studied over one year (from May 2004 to April 2005). Compared with winter, summer milk had a significantly lower concentration of saturated FA (SFA) (-8.6\%) and significantly higher contents of monounsaturated FA (MUFA) $(+19.9 \%)$, polyunsaturated FA (PUFA) $(+21.7 \%)$, conjugated linoleic acid (CLA) $(+70.1 \%)$, and trans FA other than CLA $(+56.7 \%)$. Summer and winter milk from mountains did not significantly differ with respect to the contents of branched, $n-3$ and $n-6$ FA. However, the content of the main $n$-3 FA ( $\alpha$-linolenic acid) was significantly higher in summer than in winter milk and its content was positively correlated with increasing percentages of GBF and altitude.
\end{abstract}

milk fat / fatty acid / mountain milk / winter milk / summer milk

摘要 - 瑞士山区牛乳脂肪酸组成的季节性变化。本文研究了瑞士 5 个高山地区 (海拔高度 分别为 $1247 \pm 465 \mathrm{~m}$ 和 $1136 \pm 310 \mathrm{~m}$ ) 夏季和冬季 (2004 年 5 月 -2005 年 4 月) 典型的清草基 饲料 (不同的海拔高度) 对牛乳脂肪的脂肪酸组成影响。与冬季相比,夏季牛乳脂肪中饱和脂 肪酸 $(-8.6 \%)$ 的含量较低, 但是单不饱和脂肪酸 $(+19.9 \%)$ 、多不饱和脂肪酸 $(+21.7 \%)$ 、共 轭亚油酸 $(+70.1 \%)$ 和反式脂肪酸 $(+56.7 \%)$ 的含量较高。这些高山地区的牛乳, 无论是冬季 还是夏季在支链脂肪酸、 $n-3$ 和 $n-6$ 脂肪酸含量上没有显著的差异。但是在主要的 $n-3$ 脂肪 酸 ( $\alpha$-亚麻酸) 的含量上, 夏季牛乳显著地高于冬季牛乳, 而且含量与清草基饲料比例的增加 和海拔高度呈正相关。

乳脂肪 / 脂肪酸 / 山区牛乳 / 冬季牛乳 / 夏季牛乳

Résumé - Composition en acides gras du lait de montagne suisse. Variations saisonnières. L'influence d'un affouragement typique des régions de montagne suisses (cinq régions; altitude du fourrage à base d'herbe durant les saisons estivale et hivernale : $1247( \pm 465) \mathrm{m}$ et 1136 $( \pm 310) \mathrm{m}$, respectivement $)$ sur la composition en acides gras du lait de vache a été étudiée pendant

*Corresponding author (通讯作者): marius.collomb@alp.admin.ch 
une année (de mai 2004 à avril 2005). Comparée à l'hiver, la matière grasse du lait d'été avait des concentrations significativement plus basses en acides gras saturés $(-8,6 \%)$ et plus élevées en monoinsaturés $(+19,9 \%)$, polyinsaturés $(+21,7 \%)$, acides linoléiques conjugués (ALC) $(+70,1 \%)$ et en acides gras trans $(+56,7 \%$, ALC non inclus). Les concentrations en acides gras ramifiés, $n-3$ et $n-6$ du lait d'été et d'hiver n'étaient pas significativement différentes. Cependant, la concentration de l'acide gras $n$-3 principal de la matière grasse du lait, l'acide $\alpha$-linolénique, était significativement plus élevée dans les laits d'été que dans ceux d'hiver et était positivement corrélée avec le pourcentage de fourrage à base d'herbe et avec l'altitude.

matière grasse du lait / acide gras / lait de montagne / lait d'hiver / lait d'été

\section{INTRODUCTION}

The mountain regions of Switzerland are important grassland zones and therefore well suited for milk production and cheesemaking. Milk production and processing are important economic sectors in these mountain areas and have a constructive influence on other sectors such as tourism. Thus, innovative means for maintaining and improving incomes in the dairy sector are crucial for these areas. Better knowledge of the quality of milk fat composition [20] and its influencing factors could lead to the development of products in these areas with a higher added value which should also be communicated to consumers.

Different studies carried out in Austria, Germany, France and Switzerland showed that the FA composition of bovine milk from the highlands differed from that of the lowlands $[4,9,10,12,25,28,33]$ and between seasons [17]. Generally, in milk fat from pasture-fed cows in the mountains, higher concentrations of the main $n$-3 FA ( $\alpha$-linolenic acid) were found, as well as markedly lower concentrations of SFA. Leiber et al. [27, 28] hypothesized that the increase in the $\alpha$-linolenic acid content of alpine summer milk was mainly due to pasture feeding and the absence or low amounts of concentrates.

The concentration of CLA was also very high $\left(2.51( \pm 0.28) \mathrm{g} \cdot 100 \mathrm{~g}^{-1}\right.$ fat $)$ in summer milk fat from the highlands (1275$2120 \mathrm{~m}$ ) [12]. These high values are essentially due to pasture effects but differences in the botanical composition of grass in the mountains $[4,10]$ could also modify the FA composition of milk, as reported for the lowlands in the case of grass supplemented with legumes [14,34]. Mountain pastures were characterized by a higher diversity in the botanical composition of grass than in the lowlands. Environmental conditions (temperature, more walking) which were less favorable for cows in the mountains, as well as low input feeding due essentially to grass-based feeding without or with low amounts of concentrates, could also increase the lipomobilization by cows. All these effects could explain changes in the fatty acid composition of milk fat.

Up to now, most of the studies have been carried out in a single mountain region, and rarely throughout the year [17]. Moreover, the fatty acid composition was often determined using official methods enabling one to quantify a limited number of fatty acids. The scope of this study was therefore to investigate the influence of feeding over one year in five different regions of Switzerland on the fatty acid composition of cow's milk, using a high-performance method. This study was carried out under the usual conditions of farming and management of herds, including the fraction of GBF and altitude of GBF growth.

\section{MATERIALS AND METHODS}

\subsection{Aim and approach}

During a 12-month study (from May 2004 to April 2005), bulk-tank milk 
samples from 12 dairies were collected monthly. The milk delivered to the 12 dairies was produced by 278 mountain farms with cows fed a typical mountain area diet in Switzerland. In the bulk-tank milk, 220 out of the 278 farms were represented, as in 8 dairies the farmers delivered the milk daily or twice daily and in the 4 other dairies, milk was collected every 48 hours. The dairies were located in the five mountain areas of GrisonsEngadin, Grisons-Rheinwald, Sankt Gallen-Toggenburg, Lucerne-Willisau and Berne-Emmental. The altitude of GBF growth for the summer and winter seasons was $1247( \pm 465) \mathrm{m}$ and $1136( \pm 310) \mathrm{m}$, respectively. A total of 71 bulk milk samples from the summer season (May to October) and 48 from the winter season (December to March) were analyzed. Because of changes in the diet during the transition between the two seasons the results obtained for April and November were not taken into account. Herds mainly consisted of Brown Swiss (54 ( \pm 42$) \%)$, Swiss Fleckvieh $(18( \pm 20) \%)$, Simmental (7 $( \pm 15) \%)$, Red Holstein $(14( \pm 22) \%)$, Holstein $(5( \pm 8) \%)$ and Jersey breeds $(2( \pm 4) \%)$. The average milk performance per cow was $6073( \pm 450) \mathrm{kg} \cdot 305 \mathrm{day}^{-1}$.

\subsection{Fodder composition}

Fodder composition and milk production data were obtained from a standardized questionnaire completed by the farmers (Tab. I) and were complemented in part by estimations based on the fodder proportions indicated by the farmers and the total daily dry matter consumption of the single herds. The dry matter consumption was calculated starting from daily milk yield and cow weight. Compared with winter, summer feeding was essentially characterized by significantly higher percentages of GBF, fresh grass and roughage, as well as lower fractions of grass silage, hay and milk performance concentrates. In the two seasons, the percentage of maize silage was low ( 0 to $2 \%$ of the diet). Winter feeding was essentially characterized by high percentages of hay and grass silage. Three types of concentrates were fed: cereal concentrate (energy 7.1 MJ net energy lactation (NEL) per $\mathrm{kg}$ of fresh matter (FM), $10 \%$ crude protein), protein compensation concentrate (7.0 MJ NEL $\cdot \mathrm{kg}^{-1} \mathrm{FM}, 40 \%$ crude protein) and milk performance concentrate $\left(7.1 \mathrm{MJ} \mathrm{NEL} \cdot \mathrm{kg}^{-1} \mathrm{FM}, 16 \%\right.$ crude protein) (Tab. I). In both seasons the main concentrate was cereal concentrate (about $5 \%$ of the diet). Milk performance concentrate in summer and winter contributed up to 2 and $6 \%$ of the diet, respectively, and protein compensation concentrate 0 and $1 \%$, respectively.

\subsection{Sampling and sample treatment}

Individual bulk-tank milk samples were collected in 500-mL plastic screw-top containers after stirring the bulk tank for at least 2 min. Bronopol (Merck, Dietikon, Switzerland) was added as a preservative and the containers were stored immediately at $5{ }^{\circ} \mathrm{C}$. The milk samples were centrifuged by $5000 \times g$ for $30 \mathrm{~min}$, and the resulting creams were churned at approximately $5{ }^{\circ} \mathrm{C}$. After the resulting molten butter had been filtered through a hydrophobic filter (1PS folded filter, Whatman, Bottmingen, Switzerland), the pure milk fat was collected and stored at $-20{ }^{\circ} \mathrm{C}$ until analysis.

\subsection{Methods of analysis}

After dissolution of the pure milk fat in hexane, the glycerides were trans-esterified to the corresponding methyl esters of fatty acids with a solution of potassium hydroxide in methanol [21].

Fatty acid composition was analyzed by high-resolution gas chromatography (Agilent 6890, Santa Clara, CA, USA) 
Table I. Mean content of fodder components in summer and winter.

\begin{tabular}{|c|c|c|c|c|c|c|c|c|c|}
\hline \multirow[t]{2}{*}{ Fodder } & \multicolumn{2}{|c|}{ Summer } & \multicolumn{2}{|c|}{ Winter } & \multicolumn{5}{|c|}{ Significance $(P)$} \\
\hline & $\bar{x}$ & $\mathrm{~s}_{x}$ & $\bar{x}$ & $\mathrm{~s}_{x}$ & Group & GBF & $\% / \pm$ & $\overline{\mathrm{AGBH}}$ & a $/ \pm$ \\
\hline Returned questionnaires (\%) & 69 & 24 & 69 & 20 & & & & & \\
\hline Quantity of bulk milk, $\mathrm{kg} \cdot \mathrm{day}^{-1}$ & 2695 & 1997 & 3161 & 2592 & & & & & \\
\hline Total ration, $\mathrm{kg}$ dry matter $\cdot \mathrm{day}^{-1} \cdot \mathrm{cow}^{-1}$ & 16.77 & 1.06 & 17.62 & 1.00 & $* * *$ & $* * *$ & - & $*$ & - \\
\hline Percentage grass-based feeds (GBF) & 92 & 5 & 81 & 4 & $* * *$ & & & $* * *$ & + \\
\hline Percentage of fresh grass & 74 & 23 & 0 & 1 & $* * *$ & $* * *$ & + & $*$ & + \\
\hline Percentage of grass silage & 1 & 4 & 11 & 14 & $*$ & $\mathrm{~ns}$ & & ns & \\
\hline Percentage of hay & 16 & 17 & 69 & 14 & $* * *$ & $* * *$ & - & ns & \\
\hline Percentage of whole-crop maize silage & 0 & 1 & 2 & 2 & ns & $*$ & - & ns & \\
\hline Percentage of roughage ${ }^{1}$ & 93 & 4 & 88 & 3 & $* *$ & $* * *$ & + & ns & \\
\hline Percentage of concentrates & 6.8 & 4.3 & 12.5 & 3.3 & $* *$ & $* * *$ & - & ns & \\
\hline Cereal concentrate $(\%)^{2}$ & 4.8 & 3.5 & 4.7 & 1.9 & $* * *$ & $* * *$ & - & $* * *$ & - \\
\hline Protein compensation concentrate $(\%)^{3}$ & 0.3 & 0.4 & 1.1 & 0.8 & ns & $* * *$ & - & ns & \\
\hline Milk performance concentrate $(\%)^{4}$ & 1.5 & 1.9 & 6.4 & 2.6 & $* * *$ & $* * *$ & - & $* * *$ & - \\
\hline Altitude of feed grasses growth, m & 1247 & 465 & 1136 & 310 & $* * *$ & $* * *$ & + & $* * *$ & + \\
\hline Altitude of hay growth, m & 1049 & 268 & 1135 & 298 & ns & $* *$ & - & $* * *$ & + \\
\hline Altitude of cowshed, m & 1247 & 465 & 1136 & 310 & $* * *$ & $* * *$ & + & $* * *$ & + \\
\hline
\end{tabular}

Summer $=$ May to October; Winter $=$ December to March; Group = summer versus winter groups; GBF = grass-based feed; AGBF $=$ altitude of GBF; $\bar{x}=$ mean value; $s_{x}=$ standard deviation; $P=$ probability: $*: P \leq 0.05$; **: $P \leq 0.01$; ***: $P \leq 0.001 ; \mathrm{ns}=$ non signifiant; $\pm=$ positively or negatively correlated with increasing percentage or altitude of GBF.

${ }^{1}$ Essentially constituting fresh, dried or ensiled grass and whole-crop maize but also fed straw, sugar beet pulp, fodder beets, potatoes and some other fiber-rich fresh feed.

${ }^{2}$ Energy 7.1 MJ NEL (net energy lactation), $10 \%$ crude protein.

3 7.0 MJ NEL, $40 \%$ crude protein.

4 7.1 MJ NEL, $16 \%$ crude protein.

with flame ionization detection according to Collomb and Bühler [8]. The fatty acids were separated on a capillary column, $\mathrm{CP}$ Sil $88(100 \mathrm{~m} \times 0.25 \mathrm{~mm}$ i.d., $0.20 \mu \mathrm{m}$; Varian BV, Middleburg, Netherlands), and quantified using nonanoic acid as an internal standard. The results were expressed as $\mathrm{g}$ fatty acids per $100 \mathrm{~g}$ fat. The pure methylesters of fatty acids, including CLA, were obtained from Matreya Inc., Pleasant Gap, PA, USA.

CLA isomers were analyzed by silverion $\left(\mathrm{Ag}^{+}\right.$)-HPLC (Agilent LC 1100, Santa Clara, CA, USA) equipped with a photodiode array detector $(234 \mathrm{~nm})$ using three ChromSpher Lipid columns in series (stainless steel, $250 \times 4.6 \mathrm{~mm}, 5 \mu \mathrm{m}$ particle size; Chrompack, Middleburg, Netherlands) according to Collomb et al. [12]. The solvent consisted of UV-grade hexane with $0.1 \%$ acetonitrile and $0.5 \%$ diethyl ether (flow rate $1 \mathrm{~mL} \cdot \mathrm{min}^{-1}$ ), prepared fresh daily. The injection volume was $10 \mu \mathrm{L}$, corresponding to $<250 \mu \mathrm{g}$ lipid. The HPLC areas for $t 7 c 9+t 8 c 10+c 9 t 11$ ( $t=\operatorname{trans}, c=c i s$ ) were added and used for comparison of the peak area of the three isomers from the GC chromatogram. The results were expressed as absolute values as $\mathrm{mg} \cdot \mathrm{g}^{-1}$ fat. 


\subsection{Statistical analyses}

The mean values and standard deviations of FA in milk fat from summer and winter were calculated. Analysis of covariance was performed with season as factor, and percentage and altitude of GBF as covariate. Systat for Windows version 11 [1] was used for all calculations.

\section{RESULTS AND DISCUSSION}

\subsection{Groups of fatty acids}

The concentration of milk SFA was lower in the summer than in the winter season $\left(57.95\right.$ and $63.41 \mathrm{~g} \cdot 100 \mathrm{~g}^{-1}$ fat, respectively) (Tab. II and Fig. 1). The ratio between roughage and concentrates generally affects the production of acetic acid in the rumen for fatty acid synthesis de novo, but in the current study this ratio is not very different between the two seasons. This synthesis can also be repressed by high levels of trans C18:1 FA derived either from the diet or biohydrogenation of PUFA in the rumen [38]. In the current study, the concentration of the sum of the FA C12, $\mathrm{C} 14$ and $\mathrm{C} 16$ decreased from $41.09 \mathrm{~g} \cdot 100 \mathrm{~g}^{-1}$ fat in milk fat in winter to $34.94 \mathrm{~g} \cdot 100 \mathrm{~g}^{-1}$ fat in milk fat in summer. This is an important benefit of summer milk for human health, since it is now known that only $\mathrm{C} 12, \mathrm{C} 14$ and $\mathrm{C} 16$ adversely affect plasma LDL levels [6, 30]. The concentration of SFA was also negatively correlated with increasing percentages of GBF $(r=0.76, P<0.001)$ and altitude $(r=0.39, P<0.001)$ (Tab. II, Figs. 2 and 3$)$. These results can be explained by the significantly increased percentage of grass with increasing fractions of GBF offered to cows during the summer season (Tab. I), which decreased the concentration of milk SFA $[16,24]$. Also, the feeding of grass conservation products (hay or silage) in the winter season essentially increased the SFA content of milk fat [18]. Other authors $[28,39]$ also observed that the proportion of short- and medium-chain SFA was found to be markedly lower in milk and milk products originating from cows grazing on high alpine pastures. The decreased concentration of SFA at high altitudes confirms the observations of Collomb et al. [9] (600-650 m: $58.90 \mathrm{~g} \cdot 100 \mathrm{~g}^{-1}$ fat; 900-1210 m: $54.70 \mathrm{~g} \cdot 100 \mathrm{~g}^{-1}$ fat; $1275-$ $2120 \mathrm{~m}: 52.71 \mathrm{~g} \cdot 100 \mathrm{~g}^{-1}$ fat).

Summer milk was richer in MUFA and PUFA than that of winter (Tab. II and Fig. 1), due in part to the higher dietary intake of PUFA from summer feeds (Tab. I). Increasing contents of MUFA and PUFA with increasing percentages of GBF and altitude (Tab. II, Figs. 2 and 3) were also essentially due to increasing percentages of fresh grass (Tab. I) [16, 24]. Bugaud et al. [4] suggested moreover that the higher proportion of PUFA in milk fat from the mountains compared with the lowlands may be related to a lower rate of ruminal biohydrogenation in animals in the mountains. Differences in botanical composition of grass in the mountains compared with the lowlands $[4,10]$, which modify the bacterial population in the rumen, and lipid mobilization of unsaturated FA, due to energy shortage in the cows, could explain the particularly low content of milk SFA and high content of milk MUFA and PUFA from cows grazing in the highland pastures. In mountain pastures of Switzerland, higher altitudes were associated with a reduction in the Gramineae (60 to $25 \%$ ) and an increase in dicotyledonous species (27 to 43\%), particularly Compositae, Rosaceae, Cyperaceae and Plantaginaceae $[4,9,10]$.

The concentration of total trans FA (other than CLA) in milk was significantly higher during the summer season compared with winter (Tab. II and Fig. 1). In a previous study [9] we found similar mean values at a comparable altitude in the summer season and also increasing 
Table II. Mean content $\left(\mathrm{g} \cdot 100 \mathrm{~g}^{-1}\right.$ milk fat) of groups of fatty acids in summer $(n=71)$ and winter $(n=48)$ milk.

\begin{tabular}{|c|c|c|c|c|c|c|c|c|c|}
\hline \multirow{3}{*}{$\begin{array}{l}\Sigma \text { Fatty acids } \\
\Sigma \text { short chain }^{1}\end{array}$} & \multicolumn{2}{|c|}{ Summer } & \multicolumn{2}{|c|}{ Winter } & \multicolumn{5}{|c|}{ Significance $(P)$} \\
\hline & \multirow{2}{*}{$\begin{array}{c}\bar{x} \\
8.85\end{array}$} & \multirow{2}{*}{$\begin{array}{c}\mathrm{s}_{x} \\
0.62\end{array}$} & \multirow{2}{*}{$\begin{array}{c}\bar{x} \\
9.64\end{array}$} & \multirow{2}{*}{$\begin{array}{c}\mathrm{s}_{x} \\
1.45\end{array}$} & \multirow{2}{*}{$\begin{array}{c}\text { Group } \\
\mathrm{ns}\end{array}$} & \multicolumn{2}{|c|}{$\mathrm{GBF} \% / \pm$} & \multicolumn{2}{|c|}{$\mathrm{AGBF} / \pm$} \\
\hline & & & & & & $\mathrm{ns}$ & & $* *$ & - \\
\hline$\Sigma$ medium chain ${ }^{2}$ & 40.39 & 2.75 & 46.42 & 2.12 & $* * *$ & $*$ & - & $* * *$ & - \\
\hline$\Sigma$ long chain ${ }^{3}$ & 40.87 & 3.45 & 33.95 & 2.56 & $* * *$ & $* *$ & + & $* * *$ & + \\
\hline$\Sigma$ saturated $^{4}$ & 57.95 & 2.53 & 63.41 & 1.46 & $* * *$ & $* * *$ & - & $* * *$ & - \\
\hline$\Sigma \mathrm{C} 12, \mathrm{C} 14, \mathrm{C} 16$ & 34.94 & 2.72 & 41.09 & 1.81 & $* * *$ & $* * *$ & - & $* * *$ & - \\
\hline$\Sigma \mathrm{C} 18: 1^{5}$ & 24.07 & 2.16 & 19.56 & 1.47 & $* * *$ & $* *$ & + & $* * *$ & + \\
\hline$\Sigma \mathrm{C} 18: 2^{6}$ & 4.14 & 0.58 & 3.20 & 0.33 & $* * *$ & $* * *$ & + & $* * *$ & + \\
\hline$\Sigma$ unsaturated $^{7}$ & 32.04 & 2.61 & 26.67 & 1.61 & $* * *$ & $* * *$ & + & $* * *$ & + \\
\hline$\Sigma$ monounsaturated ${ }^{8}$ & 26.56 & 2.11 & 22.16 & 1.35 & $* * *$ & $* *$ & + & $* * *$ & + \\
\hline$\Sigma$ polyunsaturated ${ }^{9}$ & 5.45 & 0.72 & 4.48 & 0.40 & $* *$ & $* * *$ & + & $* * *$ & + \\
\hline$\Sigma$ branched $^{10}$ & 2.54 & 0.23 & 2.29 & 0.12 & ns & $* * *$ & + & $*$ & + \\
\hline$\Sigma \mathrm{C} 18: 1 t^{11}$ & 4.93 & 0.90 & 3.14 & 0.59 & $* * *$ & $* * *$ & + & $* * *$ & + \\
\hline$\Sigma \mathrm{C} 18: 2 t$ without CLA $t^{12}$ & 1.13 & 0.20 & 0.74 & 0.11 & $* * *$ & $* * *$ & + & $\mathrm{ns}$ & \\
\hline$\Sigma$ C18:2 $t$ with CLA ${ }^{13}$ & 2.65 & 0.56 & 1.62 & 0.23 & $* * *$ & $* * *$ & + & $\mathrm{ns}$ & \\
\hline$\Sigma \mathrm{CLA}^{14}$ & 1.65 & 0.45 & 0.97 & 0.16 & $* * *$ & $* * *$ & + & ns & \\
\hline$\Sigma$ trans without CLA $^{15)}$ & 6.31 & 1.13 & 4.03 & 0.69 & $* * *$ & $* * *$ & + & $* *$ & + \\
\hline$\Sigma$ trans with CLA $^{16)}$ & 7.83 & 1.49 & 4.91 & 0.82 & $* * *$ & $* * *$ & + & $* *$ & + \\
\hline$\sum n-3^{17}$ & 1.65 & 0.30 & 1.37 & 0.16 & $\mathrm{~ns}$ & $* * *$ & + & $* *$ & + \\
\hline$\sum n-6^{18}$ & 2.15 & 0.27 & 2.27 & 0.28 & ns & $* * *$ & - & $* * *$ & + \\
\hline$\sum n-3 / \sum n-6$ & 0.77 & 0.15 & 0.61 & 0.11 & ns & $* * *$ & + & $* * *$ & + \\
\hline
\end{tabular}

Summer = May to October; Winter $=$ December to March; Group = summer versus winter group; GBF $=$ grass-based feed; $\mathrm{AGBF}=$ altitude of GBF; $\pm=$ positively or negatively correlated with increasing percentage or altitude of GBF; $n=$ number of samples; $\Sigma=$ sum of the concentrations; CLA = conjugated linoleic acid; $\bar{x}=$ mean value; $s_{x}=$ standard deviation; $P=$ probability: *: $P \leq 0.05$;*: $P \leq 0.01$; **: $P \leq 0.001 ; \mathrm{ns}=$ non significant $t=$ trans; $c=$ cis; NMID = non-methylene-interrupted diene; $\mathrm{MID}=$ methylene-interrupted diene.

${ }^{1} \mathrm{C} 4, \mathrm{C} 5, \mathrm{C} 6, \mathrm{C} 7, \mathrm{C} 8, \mathrm{C} 10, \mathrm{C} 10: 1$.

${ }^{2} \mathrm{C} 12, \mathrm{C} 13$ iso, C13 aiso, C12:1 c+ C13, C14 iso, C14, C15 iso, C14:1 t, C15 aiso, C14:1 c, C15, C16 iso, C16, C17 iso, $\mathrm{C} 16: 1 t, \mathrm{C} 17$ aiso, $\mathrm{C} 16: 1 \mathrm{c}$.

${ }^{3} \mathrm{C} 17, \mathrm{C} 18$ iso, C17:1 t, C18 aiso, C18, $\Sigma \mathrm{C} 18: 1, \mathrm{C} 19, \Sigma \mathrm{C} 18: 2, \mathrm{C} 20, \mathrm{C} 20: 1 t, \mathrm{C} 18: 3 c 6 c 9 c 12, \mathrm{C} 20: 1 c 5, \mathrm{C} 20: 1 c 9, \mathrm{C} 20: 1$ $c 11, \mathrm{C} 18: 3 c 9 c 12 c 15, \mathrm{C} 20: 2 c c(n-6), \mathrm{C} 22, \mathrm{C} 20: 3$ (n-6), C20:3 (n-3), C20:4 (n-6), C20:5 (EPA) (n-3), C22:5 (DPA) (n-3), $\mathrm{C} 22: 6$ (DHA) (n-3).

${ }^{4} \mathrm{C} 4, \mathrm{C} 5, \mathrm{C} 6, \mathrm{C} 7, \mathrm{C} 8, \mathrm{C} 10, \mathrm{C} 12, \Sigma$ branched (iso + aiso), C14, C15, C16, C17, C18, C19, C20, C22.

${ }^{5} \mathrm{C} 18: 1-t 4,-t 5,-t 6-8,-t 9,-t 10-11,-t 12,-t 13-14+-c 6-8,-c 9,-c 11,-c 12,-c 13, t 16+c 14$

${ }^{6} \mathrm{C} 18: 2-t t \mathrm{NMID},-t 9 t 12,-c 9 t 13+-t 8 c 12,-c 9 t 12+-c, c-\mathrm{MID}+-t 8 c 13,-t 11 c 15+-t 9 c 12,-c 9 c 12,-c 9 c 15,-c 9 t 11+-t 8 c 10$ $+-t 7 c 9,-t 11 c 13+-c 9 c 11, t 9 t 11$.

${ }^{7} \mathrm{C} 10: 1, \mathrm{C} 14: 1 c t, \mathrm{C} 16: 1 c t, \mathrm{C} 17: 1 t, \Sigma \mathrm{C} 18: 1, \Sigma \mathrm{C} 18: 2, \mathrm{C} 20: 1 t, \mathrm{C} 18: 3 c 6 c 9 c 12, \mathrm{C} 20: 1 c 5, \mathrm{C} 20: 1 c 9, \mathrm{C} 20: 1 c 11, \mathrm{C} 18: 3$ $c 9 c 12 c 15, \mathrm{C} 18: 2 c 9 t 11+t 8 c 10+t 7 c 9, \mathrm{C} 18: 2 t 11 c 13+c 9, c 11, \mathrm{C} 18: 2 t 9 t 11, \mathrm{C} 20: 2 c, c(n-6), \mathrm{C} 20: 3(n-6), \mathrm{C} 20: 3(n-3)$, $\mathrm{C} 20: 4$ (n-6), C20:5 (EPA) (n-3), C22:5 (DPA) (n-3), C22:6 (DHA) (n-3).

${ }^{8} \mathrm{C} 10: 1, \mathrm{C} 14: 1 c t, \mathrm{C} 16: 1 c t, \mathrm{C} 17: 1 \mathrm{ct}, \Sigma \mathrm{C} 18: 1, \mathrm{C} 20: 1 t, \mathrm{C} 20: 1 c 5, \mathrm{C} 20: 1 c 9, \mathrm{C} 20: 1 c 11$.

${ }^{9} \Sigma \mathrm{C} 18: 2, \mathrm{C} 18: 3 c 6 c 9 c 12, \mathrm{C} 18: 3 c 9 c 12 c 15, \mathrm{C} 20: 2 c, c(n-6), \mathrm{C} 20: 3(n-3), \mathrm{C} 20: 4$ (n-6), C20:5 (EPA) (n-3), C22:5 (DPA) $(n-3), \mathrm{C} 22: 6$ (DHA) $(n-3)$.

10) $\mathrm{C} 13$ iso + aiso, $\mathrm{C} 14$ iso, $\mathrm{C} 15$ iso + aiso, $\mathrm{C} 16$ iso, $\mathrm{C} 17$ iso + aiso, $\mathrm{C} 18$ iso + aiso.

${ }^{11} \mathrm{C} 18: 1 t 4, \mathrm{C} 18: 1 t 5, \mathrm{C} 18: 1 t 6-8, \mathrm{C} 18: 1 t 9, \mathrm{C} 18: 1 t 10-11, \mathrm{C} 18: 1 t 12, \mathrm{C} 18: 1 t 13-14+c 6-8$.

${ }^{12} \mathrm{C} 18: 2-t t \mathrm{NMID},-t 9 t 12,-c 9 t 13+-t 8 c 12,-c 9 t 12+-c, c$-MID $+-t 8 c 13,-t 11 c 15+-t 9 c 12,-t 11 c 13+-c 9 c 11$.

${ }^{13} \Sigma \mathrm{C} 18: 2 t$ without CLA + CLA $-c 9 t 11+-t 8 c 10+-t 7 c 9,-t 11 c 13+-c 9 c 11,-t 9 t 11$.

${ }^{14} \mathrm{C} 18: 2$ - $t 12 t 14,-t 11 t 13,-t 10 t 12$, $-t 9 t 11$, $-t 8 t 10,-t 7 t 9$, $-t 6 t 8,-c t 12,14,-t 11 c 13,-c 11 t 13,-t 10 c 12,-c 9 t 11,-t 8 c 10, t 7 c 9$.

${ }^{15} \mathrm{C} 14: 1 t, \mathrm{C} 16: 1 t, \mathrm{C} 17: 1 t, \mathrm{C} 20: 1 t, \Sigma \mathrm{C} 18: 1 t, \Sigma \mathrm{C} 18: 2 t$ without CLA.

${ }^{16} \Sigma t$ without CLA + CLA $-c 9 t 11+-t 8 c 10+-t 7 c 9,-c 9 c 11,-t 9 t 11$.

${ }^{17} \mathrm{C} 18: 2 t 11 c 15+\mathrm{C} 18: 2 c 9 c 15, \mathrm{C} 18: 3 c 9 c 12 c 15, \mathrm{C} 20: 3(n-3), \mathrm{C} 20: 5, \mathrm{C} 22: 5$ and $\mathrm{C} 22: 6$.

${ }^{18} \mathrm{C} 18: 1 t 12, \mathrm{C} 18: 1 c 12, \mathrm{C} 18: 2 t 9 t 12, \mathrm{C} 18: 2 c 9 t 12+c, c$-MID + t8c13, C18:2 $c 9 c 12, \mathrm{C} 18: 3 c 6 c 9 c 12, \mathrm{C} 20: 2 c c, \mathrm{C} 20: 3$ $(n-6)$ and $\mathrm{C} 20: 4(n-6)$. 

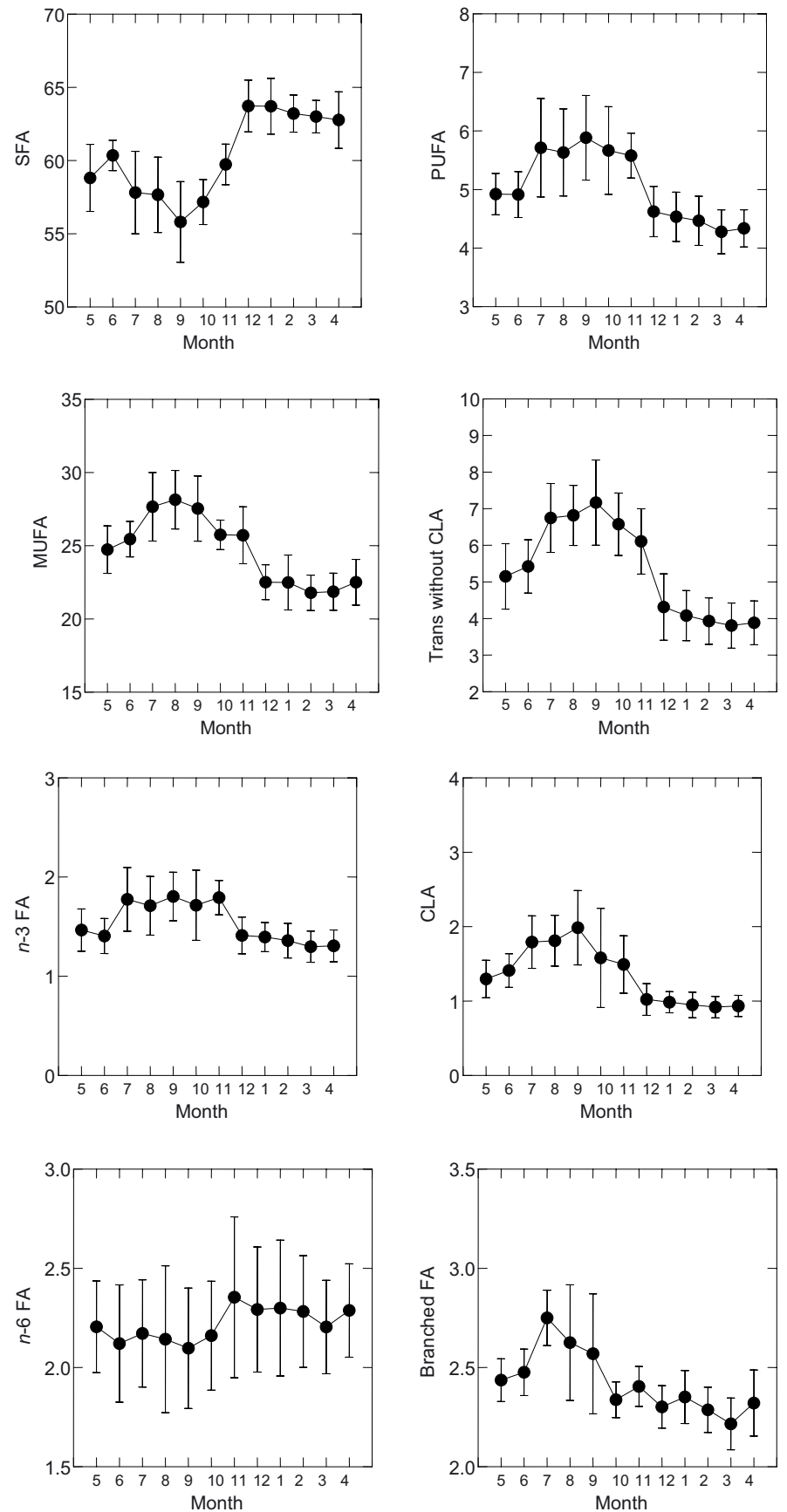

Figure 1. Concentrations ( $\mathrm{g} \cdot 100 \mathrm{~g}^{-1}$ milk fat) of different groups of FA in milk fat over one year ( $\mathrm{I}=$ standard deviation). 

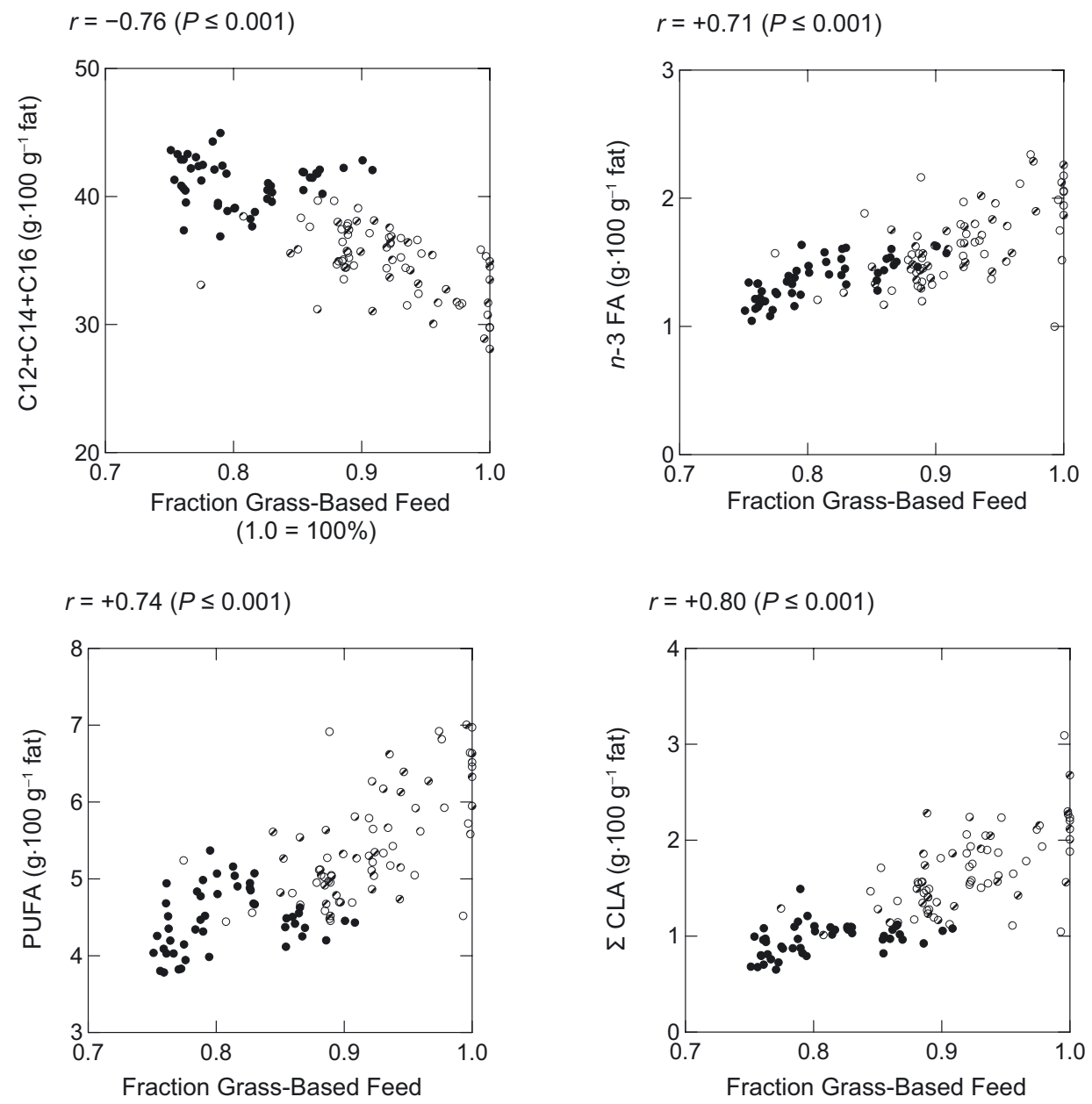

Figure 2. Influence of percentage of grass-based feed (GBF) on the content ( $\mathrm{g} \cdot 100 \mathrm{~g}^{-1}$ milk fat) of the most important health-beneficial fatty acid groups of mountain milk ( $r=$ correlation coefficient $)$ ( $\bigcirc$ summer; $\bullet$ winter).

mean values with increasing altitudes (600-650 m: $4.55 \mathrm{~g} \cdot 100 \mathrm{~g}^{-1}$ fat; 900$1210 \mathrm{~m}: 6.44 \mathrm{~g} \cdot 100 \mathrm{~g}^{-1}$ fat; $1275-2120 \mathrm{~m}$ : $8.44 \mathrm{~g} \cdot 100 \mathrm{~g}^{-1}$ fat). According to Precht and Molkentin [31], the mean contents of trans-C18:2 FA other than CLA and trans-C18:1 FA amounted to 0.63 and $3.62 \mathrm{~g} \cdot 100 \mathrm{~g}^{-1}$ fatty acid methyl ester (FAME) $(n=1756)$, respectively. Furthermore, three feeding phases, barn $(n=927)$, transition $(n=236)$ and pasture $(n=593)$, exhibited trans-C18:2 and trans-C18:1 contents of $0.46,0.66$ and $0.87 \mathrm{~g} \cdot 100 \mathrm{~g}^{-1}$ FAME, and 2.65, 3.80 and $5.08 \mathrm{~g} \cdot 100 \mathrm{~g}^{-1}$ FAME, respectively. Our results are in accordance with these reported values. Higher GBF and altitude also gave higher values of trans FA. Increased intake of substrates (linoleic or $\alpha$-linolenic acids) due to higher percentages of grass with 

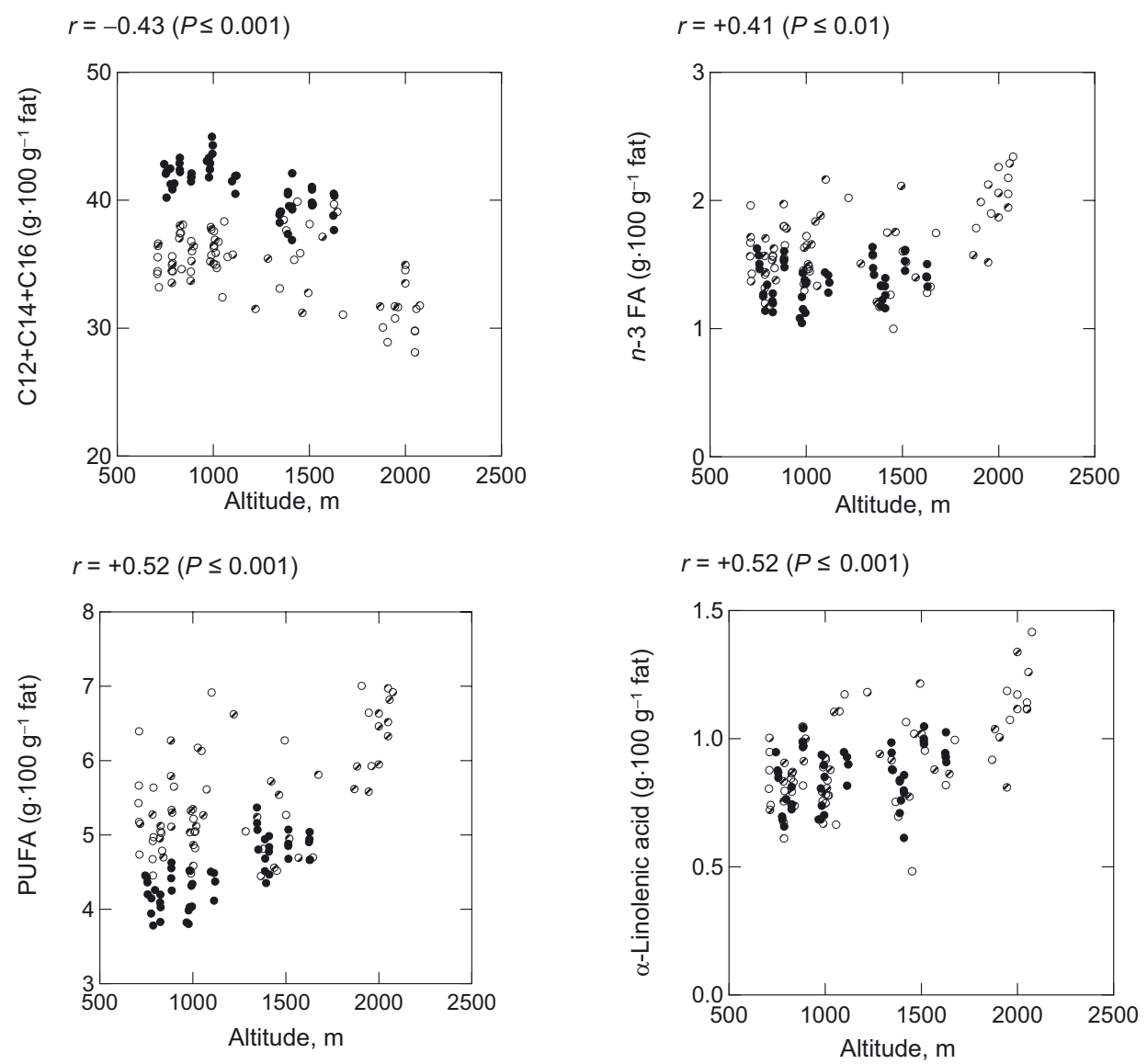

Figure 3. Influence of altitude on the content $\left(\mathrm{g} \cdot 100 \mathrm{~g}^{-1}\right.$ milk fat) of the most important healthbeneficial fatty acids or groups of fatty acids in mountain milk $(r=$ correlation coefficient) $(\mathrm{O}$ summer; $\bullet$ winter).

increasing fractions of GBF, as well as altitude (Tab. I), could explain the higher content of trans FA in the summer period [15]. It is moreover possible that cows receiving grass from mountainous areas have different bacterial populations inhabiting the rumen. Hence, such changes may encourage the growth of bacteria which do not undertake the final step of biohydrogenation. The work of Latham et al. [26], who reported changes in the amount of Butyrivibrio fibrosolvens inhabiting the rumen from $25 \%$ of total isolates in a high roughage diet to $2.3 \%$ in a low roughage diet, supports this latest proposal.

The concentration of milk fat CLA in summer was higher than in the winter season (Tab. II and Fig. 1). These values are similar to previously reported values $[7,16$, $18,24,29]$. With an increased fraction of GBF (Tab. II and Fig. 2), the CLA content also increased. According to Stanton et al. [32], higher intakes of fresh grass increased the CLA content of milk, a finding also reported by Kelly et al. [23, 24] and Dhiman et al. [16], who also found that 
the CLA content of milk increased in cows when moving from preserved to fresh grass diets. The concentration of CLA was not positively correlated with altitude. This result is not in accordance with our previous results [9] but supports the work of Leiber et al. [27,28], who found no increase in the CLA content when the same cows received alpine instead of lowland feeds.

The concentrations of branched FA found in the current study did not significantly differ between summer and winter or with increasing percentages of GBF or with altitude (Tab. II and Fig. 1). The branched FA are mostly synthesized by rumen bacteria [26] and then transferred to milk. Increasing forage-to-concentrate ratios in the diet was likely to enhance dietary neutral detergent fiber (NDF) content and thus to result in a higher branched FA content $[13,35]$. In the current study the decreased percentage of hay and concentrates combined with the increased percentages of fresh grass with increasing fractions of $\mathrm{GBF}$, as well as decreasing percentages of cereal concentrates and increasing portions of fresh grass with altitude (Tab. I), could result in a higher content of NDF in the diet.

Although the content of $n-3$ FA in milk fat was higher in summer than in winter, it did not differ significantly (Tab. II and Fig. 1). Hauswirth et al. [20] found higher concentrations of $n-3 \mathrm{FA}$ in alpine cheeses than in Emmental or Cheddar, and spoke of an alpine paradox. The values obtained by these authors in mountain areas (1.5 g.100 $\mathrm{g}^{-1}$ FAME) were similar to our reported values. In the current study, the $n-3 / n-6$ ratio in milk fat was optimal in both seasons (between $1: 1$ and 1:2, quotient 0.61 to 0.77 ), a recommended ratio of $<1: 5$ being considered highly valuable from a nutritional point of view. The increasing concentration of milk $n$ - 3 FA with increasing percentages of GBF and altitude (Tab. II, Figs. 2 and 3) found in the current study is essentially in agreement with increasing percentages of grass in the diet (Tab. I) [16, 24].

\subsection{Individual fatty acids}

Compared with winter, summer milk had significantly lower contents of the C6 to C16 SFA, higher contents of stearic acid (C18:0), most C18:1 trans FA including trans vaccenic acid ( $t \mathrm{VA}: \mathrm{C} 18: 1 t 11)$, oleic acid (C18:1 $c 9$ ), most C18:2 trans FA, and $\alpha$-linolenic acid (C18:3 $c 9 c 12 c 15)$ (Tab. III). The concentrations of linoleic acid (C18:2 $c 9 c 12)$ and of the main longchain $n$-3 FA (C20:5 (EPA), C22:5 (DPA) and $\mathrm{C} 22: 6$ ) did not differ significantly between the seasons.

A decrease in the concentrations of endogenous individual SFA in milk fat from cows on pastures compared with winter feeding has already been observed [16, 18, 29]. Conversely, the use of cereal grain concentrates generally resulted in significant increases in endogenous SFA [37]. The significantly higher concentration of stearic acid in milk fat from summer compared with winter found in this study (Tab. III) is due to extensive biohydrogenation of feed unsaturated FA in the rumen [19].

The higher content of oleic acid in milk from summer compared with winter (Tab. III) could be the result of extensive partial biohydrogenation of PUFA from feeds in the rumen, from the use of concentrates rich in oleic acid as well as from lipid mobilization due to energy shortage. The observed increase in the content of oleic acid with altitude (Tab. III) was also found by Bugaud et al. [4], who hypothesized that the decrease in temperature with altitude or greater degree of free movement of the cows on mountain pastures may induce an increase in the concentration of oleic acid in milk due to increased lipid mobilization.

The non-significant differences in linoleic acid with season support the work 
of Lock and Garnsworthy [29], who found that linoleic acid fluctuated monthly but did not vary with season. The higher content of $\alpha$-linolenic acid in milk during the summer season compared with winter (Tab. III) had been already observed [5]. The small number of results obtained with diets rich in hay [2] showed levels of milk fat $\alpha$-linolenic acid above $1.3 \mathrm{~g} \cdot 100 \mathrm{~g}^{-1}$ FAME. According to Leiber et al. [27, 28 ], increased $\alpha$-linolenic acid content in alpine summer milk could be mainly due to pasture feeding and the absence or low fractions of concentrates. The positive correlations found between the fractions of GBF as well as altitude (Tab. III and Fig. 3) and the content of $\alpha$-linolenic acid in milk confirm this hypothesis. These effects could be amplified by specific body fat mobilization in cows with alpine-specific hypoxia as well as reduced ruminal biohydrogenation due to energy shortage or secondary plant ingredients such as polyphenols and terpenoids that inhibit hydrogenating microorganisms in the rumen. Very few experiments [15] have shown the effect of grass silage on milk fat composition. Results from a review [5] suggested that milk FA produced from diets based on more than $58 \%$ silage contained more myristic (10 to $15 \%)$ and palmitic (34 to $40 \%$ ) acids, and less oleic (18 to $25 \%$ ), linoleic (0.6 to $2.0 \%$ ) and $\alpha$-linolenic ( 0.3 to $0.7 \%$ ) acids than milk produced on pastures.

The higher content of the combined FA $\mathrm{C} 18: 2 t 11 c 15$ and $t 9 c 12$ in summer milk fat than in winter could be attributed to the fermentation process in the rumen of the cow, leading to a higher concentration of $t 11 c 15 \mathrm{FA}$. It is well known that the pathway for the biohydrogenation of $\alpha$-linolenic acid (C18:3 $c 9 c 12 c 15)$ in the rumen involves an initial isomerization into a conjugated triene (C18:3 $c 9 t 11 c 15)$, followed by a reduction of double bonds at carbons 9, 15 and 11 to yield the FA C18:2 $t 11 c 15, \mathrm{C} 18: 1 t 11$ and C18:0, respectively [36].

The $\mathrm{C} 14: 1 / \mathrm{C} 14: 0$ quotient is the best indicator of $\Delta^{9}$-desaturase activity because all the C14:0 in milk fat is produced via de novo synthesis in the mammary gland; consequently, desaturation is the only source of C14:1. Increased values indicate higher $\Delta^{9}$-desaturase activity. Our values averaged over the seasons (C14:1/C14:0 FA) did not differ with the season (in summer: $0.084( \pm 0.007)$; in winter: $0.083( \pm 0.007))$. Nevertheless, the quotient was positively correlated with altitude $(P \leqslant 0.001)$ but not with increasing percentages of GBF in the diet. However, the variation in the $\Delta^{9}$-desaturase activity between herds and animals was very large.

\subsection{CLA isomers}

Except for the $t 8 t 10, t 7 t 9, t 6 t 8$ and $t 11 c 13$ isomers, the concentrations of all other CLA isomers were significantly higher in summer milk than in milk from the winter season (Tab. IV). Also, a trend towards higher contents of the isomer $t 11 c 13$ in summer milk than in winter milk was shown. In both types of milk the concentration of the CLA isomer $c 9 t 11$ was highest, followed by the $t 11 c 13$ and $t 7 c 9$ isomers. The concentration of the $c 9 t 11$ isomer in summer and winter milk fat corresponded to 85.2 and $83.2 \%$ of all CLA isomers, respectively.

As in the current study, higher concentrations of the most important CLA isomers were generally observed in summer [11]. The contents of the CLA isomers in summer milk fat found in the current study were similar to those found by Collomb et al. [12] at a similar altitude. The trend was that the content was highest when fresh pasture was plentiful, and decreased throughout the grazing season [29]. On the contrary, in this study the CLA content increased during the pasture feeding season 
Table III. Mean content ( $\mathrm{g} \cdot 100 \mathrm{~g}^{-1}$ milk fat) of individual fatty acids in summer $(n=71)$ and winter $(n=48)$ milk.

\begin{tabular}{|c|c|c|c|c|c|c|c|c|c|}
\hline \multirow[t]{2}{*}{$\Sigma$ Fatty acids } & \multicolumn{2}{|c|}{ Summer } & \multicolumn{2}{|c|}{ Winter } & \multicolumn{5}{|c|}{ Significance $(P)$} \\
\hline & $\bar{x}$ & $\mathrm{~s}_{x}$ & $\bar{x}$ & $\mathrm{~s}_{x}$ & Group & \multicolumn{2}{|c|}{ GBF $\% / \pm$} & \multicolumn{2}{|c|}{$\mathrm{AGBF} / \pm$} \\
\hline \multicolumn{10}{|c|}{ FA concentrations which changed significantly between summer and winter } \\
\hline C6 & 1.93 & 0.13 & 2.15 & 0.06 & $* * *$ & $* * *$ & - & $* * *$ & - \\
\hline $\mathrm{C} 7$ & 0.01 & 0.01 & 0.02 & 0.00 & $*$ & ns & & $* * *$ & - \\
\hline $\mathrm{C} 8$ & 1.07 & 0.11 & 1.21 & 0.05 & $* * *$ & $* * *$ & - & $* * *$ & - \\
\hline $\mathrm{C} 10$ & 2.19 & 0.29 & 2.58 & 0.19 & $* * *$ & $*$ & - & $* * *$ & - \\
\hline C10:1 & 0.26 & 0.03 & 0.31 & 0.03 & $* * *$ & $\mathrm{~ns}$ & & $* * *$ & - \\
\hline $\mathrm{C} 12$ & 2.41 & 0.31 & 2.83 & 0.24 & $* * *$ & $*$ & - & $* * *$ & - \\
\hline $\mathrm{C} 12: 1 c+\mathrm{C} 13$ & 0.13 & 0.02 & 0.14 & 0.02 & $* * *$ & $\mathrm{~ns}$ & & $* * *$ & - \\
\hline $\mathrm{C} 13$ iso & 0.04 & 0.01 & 0.03 & 0.00 & $* * *$ & $* * *$ & + & $*$ & + \\
\hline C13 aiso & 0.07 & 0.01 & 0.08 & 0.01 & $* *$ & ns & & $* * *$ & - \\
\hline $\mathrm{C} 14$ iso & 0.13 & 0.02 & 0.14 & 0.02 & $* * *$ & $\mathrm{~ns}$ & & $* * *$ & + \\
\hline C14 & 8.89 & 0.77 & 10.15 & 0.44 & $* * *$ & $*$ & - & $* * *$ & - \\
\hline $\mathrm{C} 14: 1 c$ & 0.75 & 0.09 & 0.84 & 0.10 & $* *$ & $\mathrm{~ns}$ & & $* * *$ & - \\
\hline $\mathrm{C} 15$ & 1.08 & 0.08 & 1.09 & 0.10 & $* * *$ & $* * *$ & + & $* * *$ & - \\
\hline $\mathrm{C} 16$ & 23.64 & 1.76 & 28.12 & 1.25 & $* * *$ & $* * *$ & - & $* * *$ & - \\
\hline $\mathrm{C} 16: 1 t$ & 0.20 & 0.05 & 0.10 & 0.02 & $* * *$ & $* * *$ & + & ns & \\
\hline $\mathrm{C} 16: 1 c$ & 1.06 & 0.08 & 1.14 & 0.14 & $*$ & $\mathrm{~ns}$ & & $* * *$ & - \\
\hline $\mathrm{C} 17$ iso & 0.38 & 0.03 & 0.31 & 0.02 & $* * *$ & $* * *$ & + & $\mathrm{ns}$ & \\
\hline $\mathrm{C} 17: 1 t$ & 0.02 & 0.01 & 0.00 & 0.01 & $*$ & $* * *$ & + & $\mathrm{ns}$ & \\
\hline $\mathrm{C} 18$ & 9.84 & 0.88 & 8.50 & 0.84 & $* * *$ & $\mathrm{~ns}$ & & $* * *$ & + \\
\hline $\mathrm{C} 18: 1 t 9$ & 0.27 & 0.03 & 0.24 & 0.04 & $* * *$ & $\mathrm{~ns}$ & & $* * *$ & + \\
\hline $\mathrm{C} 18: 1 t 10+t 11(t \mathrm{VA})$ & 3.66 & 0.82 & 2.08 & 0.42 & $* * *$ & $* * *$ & + & $* *$ & + \\
\hline $\mathrm{C} 18: 1 t 13-14+c 6-8$ & 0.60 & 0.08 & 0.47 & 0.09 & $* * *$ & $\mathrm{~ns}$ & & $\mathrm{~ns}$ & \\
\hline $\mathrm{C} 18: 1 c 9$ & 18.15 & 1.59 & 15.51 & 1.02 & $* * *$ & $\mathrm{~ns}$ & & $* * *$ & + \\
\hline $\mathrm{C} 18: 1 t 16+c 14$ & 0.31 & 0.04 & 0.24 & 0.04 & $* * *$ & $*$ & + & $*$ & + \\
\hline C18:2 ttNMID & 0.16 & 0.03 & 0.10 & 0.02 & $* * *$ & $* * *$ & + & ns & \\
\hline $\mathrm{C} 18: 2 t 9 t 12$ & 0.01 & 0.01 & 0.00 & 0.01 & $*$ & $\mathrm{~ns}$ & & $\mathrm{~ns}$ & \\
\hline $\mathrm{C} 18: 2 c 9 t 13+(t 8 c 12)$ & 0.23 & 0.03 & 0.15 & 0.02 & $* * *$ & $* * *$ & + & $\mathrm{ns}$ & \\
\hline $\mathrm{C} 18: 2 c 9 t 12+(c c-\mathrm{MID}+t 8 c 13)$ & 0.26 & 0.02 & 0.23 & 0.02 & $* * *$ & $\mathrm{~ns}$ & & $* * *$ & + \\
\hline $\mathrm{C} 18: 2 t 11 c 15+t 9 c 12$ & 0.47 & 0.13 & 0.26 & 0.06 & $* *$ & $* * *$ & + & $\mathrm{ns}$ & \\
\hline $\mathrm{C} 18: 3 c 6 c 9 c 12$ & 0.02 & 0.01 & 0.02 & 0.00 & $*$ & $*$ & + & $\mathrm{ns}$ & \\
\hline $\mathrm{C} 18: 3 c 9 c 12 c 15$ & 0.92 & 0.18 & 0.85 & 0.11 & $* *$ & $* * *$ & + & $* * *$ & + \\
\hline $\mathrm{C} 20$ & 0.17 & 0.02 & 0.16 & 0.02 & $*$ & $* *$ & + & $* * *$ & + \\
\hline $\mathrm{C} 20: 1 t$ & 0.03 & 0.01 & 0.03 & 0.00 & $* * *$ & $* *$ & + & $*$ & + \\
\hline $\mathrm{C} 20: 1 c 9$ & 0.15 & 0.02 & 0.13 & 0.01 & $* *$ & $\mathrm{~ns}$ & & $* * *$ & + \\
\hline $\mathrm{C} 20: 2 c c(n-6)$ & 0.02 & 0.01 & 0.03 & 0.00 & $*$ & $\mathrm{~ns}$ & & $*$ & + \\
\hline C20:3 (n-6) & 0.05 & 0.01 & 0.05 & 0.01 & $* *$ & $* * *$ & - & $* * *$ & + \\
\hline $\mathrm{C} 20: 3(n-3)$ & 0.02 & 0.01 & 0.03 & 0.01 & $* * *$ & $\mathrm{~ns}$ & & $\mathrm{~ns}$ & \\
\hline
\end{tabular}


Table III. Continued.

\begin{tabular}{|c|c|c|c|c|c|c|c|c|c|}
\hline \multirow[t]{2}{*}{$\Sigma$ Fatty acids } & \multicolumn{2}{|c|}{ Summer } & \multicolumn{2}{|c|}{ Winter } & \multicolumn{5}{|c|}{ Significance $(P)$} \\
\hline & $\bar{x}$ & $\mathrm{~s}_{x}$ & $\bar{x}$ & $\mathrm{~s}_{x}$ & Group & \multicolumn{2}{|c|}{ GBF $\% / \pm$} & \multicolumn{2}{|c|}{$\mathrm{AGBF} / \pm$} \\
\hline \multicolumn{10}{|c|}{ FA concentrations which did not change between summer and winter } \\
\hline $\mathrm{C} 4$ & 3.36 & 0.22 & 3.55 & 0.20 & ns & $*$ & - & $*$ & + \\
\hline $\mathrm{C} 5$ & 0.04 & 0.01 & 0.04 & 0.01 & ns & ns & & ns & \\
\hline $\mathrm{C} 14: 1 t$ & 0.00 & 0.01 & 0.00 & 0.00 & ns & $\mathrm{ns}$ & & ns & \\
\hline C15 iso & 0.28 & 0.04 & 0.25 & 0.02 & ns & $* * *$ & + & $* *$ & + \\
\hline C15 aiso & 0.52 & 0.06 & 0.46 & 0.03 & ns & $* * *$ & + & $* *$ & + \\
\hline C16 iso & 0.26 & 0.03 & 0.26 & 0.02 & $\mathrm{~ns}$ & $\mathrm{~ns}$ & & $* * *$ & + \\
\hline C17 & 0.61 & 0.05 & 0.58 & 0.04 & ns & $* * *$ & + & $* * *$ & + \\
\hline C17 aiso & 0.55 & 0.09 & 0.48 & 0.03 & $\mathrm{~ns}$ & $* * *$ & + & $\mathrm{ns}$ & \\
\hline $\mathrm{C} 18$ iso & 0.07 & 0.01 & 0.06 & 0.01 & ns & $\mathrm{ns}$ & & $*$ & + \\
\hline C18 aiso & 0.25 & 0.03 & 0.22 & 0.03 & ns & $* * *$ & + & $\mathrm{ns}$ & \\
\hline $\mathrm{C} 18: 1 t 4$ & 0.02 & 0.01 & 0.01 & 0.01 & ns & $\mathrm{ns}$ & & $* * *$ & + \\
\hline C18:1 t5 & 0.01 & 0.01 & 0.01 & 0.01 & $\mathrm{~ns}$ & ns & & $* * *$ & + \\
\hline C18:1 t6-8 & 0.16 & 0.04 & 0.14 & 0.04 & ns & ns & & $* * *$ & + \\
\hline $\mathrm{C} 18: 1 t 12$ & 0.20 & 0.04 & 0.19 & 0.05 & $\mathrm{~ns}$ & $\mathrm{~ns}$ & & $* *$ & + \\
\hline $\mathrm{C} 18: 1 c 11$ & 0.51 & 0.07 & 0.48 & 0.05 & ns & ns & & $*$ & + \\
\hline $\mathrm{C} 18: 1 c 12$ & 0.12 & 0.02 & 0.15 & 0.04 & ns & $* * *$ & - & $* * *$ & + \\
\hline $\mathrm{C} 18: 1 c 13$ & 0.05 & 0.01 & 0.05 & 0.01 & ns & $\mathrm{ns}$ & & $\mathrm{ns}$ & \\
\hline $\mathrm{C} 18: 2 c 9 c 12$ & 1.38 & 0.22 & 1.50 & 0.20 & ns & $* * *$ & - & $* * *$ & + \\
\hline $\mathrm{C} 18: 2 c 9 c 15$ & 0.03 & 0.01 & 0.04 & 0.01 & $\mathrm{~ns}$ & $\mathrm{~ns}$ & & $* *$ & - \\
\hline $\mathrm{C} 18: 2 t 11 c 13+c 9 c 11$ & 0.08 & 0.03 & 0.05 & 0.02 & ns & $* * *$ & + & $*$ & + \\
\hline $\mathrm{C} 18: 2 t 9 t 11$ & 0.02 & 0.01 & 0.03 & 0.01 & $\mathrm{~ns}$ & $\mathrm{~ns}$ & & ns & \\
\hline C19 & 0.10 & 0.02 & 0.09 & 0.01 & ns & ns & & ns & \\
\hline $\mathrm{C} 20: 1 c 5$ & 0.01 & 0.01 & 0.00 & 0.01 & $\mathrm{~ns}$ & ns & & ns & \\
\hline $\mathrm{C} 20: 1 c 11$ & 0.04 & 0.01 & 0.05 & 0.01 & $\mathrm{~ns}$ & $*$ & - & $*$ & + \\
\hline $\mathrm{C} 20: 4(n-6)$ & 0.08 & 0.02 & 0.10 & 0.01 & ns & $* * *$ & - & ns & \\
\hline $\mathrm{C} 20: 5$ (EPA) $(n-3)$ & 0.08 & 0.01 & 0.08 & 0.01 & ns & $*$ & + & $* *$ & - \\
\hline $\mathrm{C} 22$ & 0.07 & 0.01 & 0.07 & 0.01 & $\mathrm{~ns}$ & ns & & $* * *$ & + \\
\hline C22:5 (DPA) $(n-3)$ & 0.11 & 0.01 & 0.10 & 0.01 & ns & $*$ & + & $\mathrm{ns}$ & \\
\hline C22:6 (DHA) $(n-3)$ & 0.01 & 0.01 & 0.01 & 0.01 & ns & ns & & $\mathrm{ns}$ & \\
\hline Quotient C14:1/C14 & 0.084 & 0.007 & 0.083 & 0.007 & $\mathrm{~ns}$ & ns & & $* * *$ & + \\
\hline
\end{tabular}

Summer $=$ May to October; Winter $=$ December to March; Group $=$ summer versus winter group GBF $=$ grass-based feed; $\mathrm{AGBF}=$ altitude of GBF; $\pm=$ positively or negatively correlated with increasing percentage or altitude of GBF; $n=$ number of samples; $\Sigma=$ sum of the concentrations; CLA = conjugated linoleic acid; $t=$ trans; $c=c i s ; t \mathrm{VA}=$ trans vaccenic acid; NMID = non-methylene-interrupted diene; MID = methylene-interrupted diene; $\bar{x}=$ mean value; $s_{x}=$ standard deviation; $P=$ probability: $*: P \leq 0.05 ; * *: P \leq 0.01 ; * *: P \leq 0.001 ; \mathrm{ns}=$ non significant. 
Table IV. Mean content ( $\mathrm{mg} \cdot \mathrm{g}^{-1}$ fat) of conjugated linoleic acid (CLA) isomers in summer $(n=71)$ and winter $(n=48)$ milk.

\begin{tabular}{|c|c|c|c|c|c|c|c|c|c|}
\hline \multirow{3}{*}{$\begin{array}{l}\text { CLA } \\
\text { C18:2t12t14 }\end{array}$} & \multicolumn{2}{|c|}{ Summer } & \multicolumn{2}{|c|}{ Winter } & \multicolumn{5}{|c|}{ Significance $(P)$} \\
\hline & \multirow{2}{*}{$\begin{array}{c}\bar{x} \\
0.16\end{array}$} & \multirow{2}{*}{$\frac{\mathrm{s}_{x}}{0.04}$} & \multirow{2}{*}{$\begin{array}{c}\bar{x} \\
0.08\end{array}$} & \multirow{2}{*}{$\begin{array}{c}\mathrm{s}_{x} \\
0.02\end{array}$} & \multirow{2}{*}{$\begin{array}{c}\text { Group } \\
* * *\end{array}$} & \multicolumn{2}{|c|}{ GBF $\% / \pm$} & \multicolumn{2}{|c|}{$\mathrm{AGBF} / \pm$} \\
\hline & & & & & & $* * *$ & + & $* * *$ & + \\
\hline $\mathrm{C} 18: 2 t 11 t 13$ & 0.33 & 0.09 & 0.17 & 0.05 & $* * *$ & $* * *$ & + & $* * *$ & - \\
\hline $\mathrm{C} 18: 2 t 10 t 12$ & 0.03 & 0.01 & 0.03 & 0.01 & $* *$ & $* * *$ & - & $* * *$ & + \\
\hline $\mathrm{C} 18: 2 t 9 t 11$ & 0.15 & 0.03 & 0.13 & 0.01 & $*$ & $* *$ & + & ns & \\
\hline $\mathrm{C} 18: 2 t 8 t 10$ & 0.02 & 0.01 & 0.02 & 0.01 & ns & $*$ & - & $* * *$ & + \\
\hline $\mathrm{C} 18: 2 t 7 t 9$ & 0.09 & 0.02 & 0.09 & 0.02 & $\mathrm{~ns}$ & ns & & $* * *$ & + \\
\hline $\mathrm{C} 18: 2 t 6 t 8$ & 0.03 & 0.02 & 0.05 & 0.01 & ns & $* *$ & - & $* * *$ & + \\
\hline $\mathrm{C} 18: 2 c / t 12,14$ & 0.05 & 0.01 & 0.03 & 0.01 & $* * *$ & $* * *$ & + & $* * *$ & - \\
\hline $\mathrm{C} 18: 2 t 11 c 13$ & 0.84 & 0.33 & 0.51 & 0.19 & ns & $* * *$ & + & $* *$ & + \\
\hline $\mathrm{C} 18: 2 c 11 t 13$ & 0.03 & 0.01 & 0.02 & 0.01 & $* *$ & $* * *$ & + & $\mathrm{ns}$ & \\
\hline $\mathrm{C} 18: 2 t 10 c 12$ & 0.02 & 0.01 & 0.02 & 0.01 & $* * *$ & $* * *$ & - & $* * *$ & + \\
\hline $\mathrm{C} 18: 2 c 9 t 11$ & 14.03 & 4.02 & 8.05 & 1.34 & $* * *$ & $* * *$ & + & ns & \\
\hline $\mathrm{C} 18: 2 t 8 c 10$ & 0.24 & 0.06 & 0.12 & 0.02 & $* * *$ & $* * *$ & + & $*$ & + \\
\hline $\mathrm{C} 18: 2 t 7 c 9$ & 0.43 & 0.08 & 0.37 & 0.06 & $* * *$ & ns & & $* * *$ & + \\
\hline CLA $t 11 c 13 /$ CLA $t 7 \mathrm{c} 9$ & 1.90 & 0.60 & 1.40 & 0.48 & $\mathrm{~ns}$ & $* * *$ & + & $\mathrm{ns}$ & \\
\hline$\Sigma$ CLA & 16.46 & 4.54 & 9.68 & 1.62 & $* * *$ & $* * *$ & + & ns & \\
\hline
\end{tabular}

Summer $=$ May to October; Winter $=$ December to March; Group $=$ summer versus winter group; GBF $=$ grass-based feed; $\mathrm{AGBF}=$ altitude of GBF; $\pm=$ positively or negatively correlated with increasing percentage or altitude of GBF; $n=$ number of samples; $\Sigma=$ sum of the concentrations; $t=$ trans; $c=c i s$; NMID = non-methylene-interrupted diene; MID = methylene-interrupted diene; $\bar{x}=$ mean value; $s_{x}=$ standard deviation; $P=$ probability: $*: P \leq 0.05 ; * *: P \leq 0.01$; ***: $P \leq 0.001$; ns $=$ non significant.

from May to September (Fig. 1). Normally, the $t 7 c 9$ isomer is the second most predominant CLA isomer in ruminant fat [3]. The results found in the current study showed that the concentration of the CLA isomer $t 11 c 13$ was the second most predominant isomer in milk fat from cows fed both winter and summer feeds in the mountains. According to a hypothesis by Kraft et al. [25], $\alpha$-linolenic acid was the indirect precursor of the $t 11 c 13$ isomer. The increased content of this isomer with increasing percentage of GBF and with altitude confirmed the observation of Collomb et al. [9, 12] and Leiber et al. [27] that this CLA isomer could be a useful indicator of grass feeding as well as of milk products of alpine origin.

\section{CONCLUSION}

The results from the current study show that compared with winter the concentration of endogenous SFA in milk fat was lowest in summer and MUFA, PUFA, CLA and trans FA highest. Generally, grass supplemented with concentrates in the summer season, or high intakes of hay combined with concentrates in winter led to an increase in the SFA content and a decrease in the PUFA content, including 
CLA in milk fat. Milk fat from the mountains appears particularly interesting from the nutritional point of view in the summer season because of the marked reduction of the SFA content, particularly of the SFA C12, C14 and C16, which adversely affect plasma LDL levels. The higher content of the main $n$ - 3 FA ( $\alpha$-linolenic acid) in milk fat from the mountains in the summer season than in milk fat from the lowlands is now generally recognized and confirmed by the increasing values with altitude in this study. In the winter season, the concentration of milk $\alpha$-linolenic acid was not very different from that found in the summer season despite lower intake due to loss during grass drying. The relatively higher content of tVA in the summer season should be considered as positive since evidence [22] indicates that it may be transformed endogenously into healthpromoting CLA. The increased content of the CLA $t 11 c 13$ with increasing percentage of GBF and with altitude indicated that this isomer could be a useful indicator of grass feeding as well as of milk products of alpine origin.

Acknowledgements: The authors thank their colleagues M. Spahni, P. Malke, R. Gauch, A. Liniger and F. Clerc for their careful technical assistance.

\section{REFERENCES}

[1] Anonymous, Systat for Windows version 11, Chicago, USA, SPSS Inc (2004).

[2] Bartsch B.D., Graham E.R.B., McLean D.M., Protein and fat composition and some manufacturing properties of milk from dairy cows fed hay and concentrate in various ratios, Austr. J. Agric. Res. 30 (1979) 191-199.

[3] Bauman D.E., Corl B.A., Peterson D.G., The biology of conjugated linoleic acids in ruminants, in: Sébédio J.-L., Christie W.W., Adlof R. (Eds.), Advances in Conjugated
Linoleic Acid Research, vol. 2, AOAC Press, Champaign, USA, 2003, pp. 146-173.

[4] Bugaud C., Buchin S., Coulon J.B., Hauwuy A., Dupont D., Influence of alpine pastures on plasmin activity, fatty acid and volatile compound composition of milk, Lait 81 (2001) 401-414.

[5] Chilliard Y., Ferlay A., Doreau M., Effect of different types of forages, animal fat or marine oils in cow's diet on milk fat secretion and composition, especially conjugated linoleic acid (CLA) and polyunsaturated fatty acids, Livest. Prod. Sci. 70 (2001) 31-48.

[6] Chilliard Y., Ferlay A., Mansbridge R.M., Doreau M., Ruminant milk fat plasticity: nutritional control of saturated, polyunsaturated, trans and conjugated fatty acids, Ann. Zootech. 49 (2000) 181-205.

[7] Chouinard P.Y., Corneau L., Butler W.R., Chilliard Y., Drackley J.K., Bauman D.E., Effect of dietary lipid source on conjugated linoleic acid concentrations in milk fat, $\mathrm{J}$. Dairy Sci. 84 (2001) 680-690.

[8] Collomb M., Bühler T., Analyse de la composition en acides gras de la graisse de lait. I. Optimisation et validation d'une méthode générale à haute résolution, Trav. Chim. Alim. Hyg. 91 (2000) 306-332.

[9] Collomb M., Bütikofer U., Sieber R., Jeangros B., Bosset J.O., Composition of fatty acids in cow's milk fat produced in the lowlands, mountains and highlands of Switzerland using high-resolution gas chromatography, Int. Dairy J. 12 (2002) 649-659.

[10] Collomb M., Bütikofer U., Sieber R., Jeangros B., Bosset J.O., Correlation between fatty acids in cows' milk fat produced in the lowlands, mountains and highlands of Switzerland and botanical composition of the fodder, Int. Dairy J. 12 (2002) 661-666.

[11] Collomb M., Schmid A., Sieber R., Wechsler D., Ryhänen E.-L., Conjugated linoleic acid in milk fat: variation and physiological effects, Int. Dairy J. 16 (2006) 1347-1361.

[12] Collomb M., Sieber R., Bütikofer U., CLA isomers in milk fat from cows fed diets with high levels of unsaturated fatty acids, Lipids 39 (2004) 355-364.

[13] Couvreur S., Hurtaud C., Marnet P.G., Faverdin P., Peyraud J.L., Composition of 
milk fat from cows selected for milk fat globule size and offered either pasture or a corn silage-based diet, J. Dairy Sci. 90 (2007) 392-403.

[14] Dewhurst R.J., Fisher W.J., Tweed J.K.S., Wilkins R.J., Comparison of grass and legume silages for milk production. 1 . Production responses with different levels of concentrate, J. Dairy Sci. 86 (2003) 25982611.

[15] Dewhurst R.J., Shingfield K.J., Lee M.R.F., Scollan N.D., Increasing the concentrations of beneficial polyunsaturated fatty acids in milk produced by dairy cows in high-forage systems, Anim. Feed Sci. Technol. 131 (2006) 168-206.

[16] Dhiman T.R., Arnand G.R., Satter L.D., Pariza M.W., Conjugated linoleic acid content of milk from cows fed different diets, J. Dairy Sci. 82 (1999) 2146-2156.

[17] Ferlay A., Agabriel C., Sibra C., Journal C., Martin B., Chilliard Y., Tanker milk variability in fatty acids according to farm feeding and husbandry practices in a French semimountain area, Dairy Sci. Technol. 88 (2008) 193-215.

[18] Ferlay A., Martin B., Pradel P., Coulon J.B., Chilliard Y., Influence of grass-based diets on milk fatty acid composition and milk lipolytic system in Tarentaise and Montbéliarde cow breeds, J. Dairy Sci. 89 (2006) 4026-4041.

[19] Harfoot C.G., Hazlewood G.P., Lipid metabolism in the rumen, in: Hobson P.N., Stewart C.S. (Eds.), The Rumen Microbial Ecosystem, 2nd edn., Chapman and Hall, London, UK, 1997, pp. 382-426.

[20] Hauswirth C.B., Scheeder M.R.L., Beer J.H., High $\omega-3$ fatty acid content in alpine cheese, the basis for an alpine paradox, Circulation 109 (2004) 103-107.

[21] International Organization for Standardization (ISO), Milk fat, Preparation of fatty acid methyl ester, ISO standard 15884 (2002).

[22] Ip C., Banni S., Angioni E., Carta G., McGinley J., Thompson H.J., Barbano D., Bauman D., Conjugated linoleic acidenriched butter fat alters mammary gland morphogenesis and reduces cancer risk in rats, J. Nutr. 129 (1999) 2135-2142.
[23] Kelly M.L., Berry J.R., Dwyer D.A., Griinari J.M., Chouinard P.Y., van Amburgh M.E., Bauman D.E., Dietary fatty acid sources affect conjugated linoleic acid (CLA) concentrations in milk from lactating dairy cows, J. Nutr. 128 (1998) 881-885.

[24] Kelly M.L., Kolver E.S., Bauman D.E., van Amburgh M.E., Muller L.D., Effect of intake of pasture on concentrations of conjugated linoleic acid in milk of lactating cows, J. Dairy Sci. 81 (1998) 1630-1636.

[25] Kraft J., Collomb M., Möckel P., Sieber R., Jahreis G., Differences in CLA isomer distribution of cow's milk lipids, Lipids 38 (2003) 657-664.

[26] Latham M.J., Storry J.E., Sharpe M.E., Effect of low roughage diets on the microflora and lipid metabolism in the rumen, Appl. Microbiol. 24 (1972) 871-877.

[27] Leiber F., Kreuzer M., Nigg D., Wettstein H.R., Scheeder M.R.L., A study on the causes for the elevated $n-3$ fatty acids in cows' milk of alpine origin, Lipids 40 (2005) 191-202.

[28] Leiber F., Scheeder M.R.L., Wettstein H.R., Kreuzer M., Milk fatty acid profile of cows under the influence of alpine hypoxia and high mountainous forage quality, J. Anim. Feed Sci. 13 (2004) 693-696.

[29] Lock A.L., Garnsworthy P.C., Seasonal variation in milk conjugated linoleic acid and $\Delta^{9}$-desaturase activity in dairy cows, Livest. Prod. Sci. 79 (2003) 47-59.

[30] Maijala K., Cow milk and human development and well-being, Livest. Prod. Sci. 65 (2000) 1-18.

[31] Precht D., Molkentin J., Analysis and seasonal variation of conjugated linoleic acid and further cis-/trans-isomers of C18:1 and C18:2 in bovine milk fat, Kieler Milchwirt. Forschungsber. 51 (1999) 63-78.

[32] Stanton C., Lawless F., Kjellmer G., Harrington D., Devery R., Connolly J.F., Murphy J., Dietary influences on bovine milk cis-9,trans-11-conjugated linoleic acid content, J. Food Sci. 62 (1997) 1083-1086.

[33] Tschager E., Zangerl P., Sebastian H.J., Kneifel W., Lang E.C., Legner F., Organoleptische, technologische und ernährungsphysiologische Eigenschaften von 
Almmilch, Milchwirt. Ber. Wolfpassing Rotholz 120 (1994) 152-157.

[34] Van Dorland H.A., Effect of white clover and red clover addition to ryegrass on nitrogen use efficiency, performance, milk quality, and eating behaviour in lactating dairy cows, Thesis ETH Zürich, no 16867 (2006).

[35] Vlaeminck B., Fievez V., Cabrita A.R.J., Fonseca A.J.M., Dewhurst R.J., Factors affecting odd- and branched-chain fatty acids in milk: a review, Anim. Feed Sci. Technol. 131 (2006) 389-417.

[36] Wilde P.F., Dawson R.M., The biohydrogenation of $\alpha$-linolenic acid and oleic acid by rumen microorganisms, Biochem. J. 98 (1966) 469-475.

[37] Wijesundera C., Shen Z., Wales W.J., Dalley D.E., Effects of cereal grain and fibre supplements on the fatty acid composition of milk fat of grazing dairy cows in early lactation, $\mathrm{J}$. Dairy Res. 70 (2003) 257-265.

[38] Wonsil B.J., Herbein J.H., Watkins B.A., Dietary and ruminally derived trans-18:1 fatty acids alter bovine milk lipids, J. Nutr. 124 (1994) 556-565.

[39] Zeppa G., Giordano M., Gerbi V., Arlorio M., Fatty acid composition of Piedmont "Ossolano Cheese", Lait 83 (2003) 167-173. 